\title{
Survey and Identification of Macroinvertebrates Found in Some Ponds in Makurdi, Benue State Nigeria
}

\author{
Ada Raymond Tersoo ${ }^{1, ~}$, Iorshagher Sixtus Terngu ${ }^{2}$, Akogwu Emmanuel Akogwu ${ }^{3}$ \\ ${ }^{1}$ Department of Biological Sciences, Faculty of Science, Benue State University, Makurdi, Nigeria \\ ${ }^{2}$ Department of Animal Production, Faculty of Animal Science, University of Agriculture, Makurdi, Nigeria \\ ${ }^{3}$ Department of Biological Sciences, Faculty of Science, University of Agriculture, Makurdi, Nigeria \\ Email address: \\ tersooada@yahoo.com (A. R. Tersoo), terngusixtus@gmail.com (I. S. Terngu), akogwuteeyamz@gmail.com (A. E. Akogwu) \\ *Corresponding author
}

\section{To cite this article:}

Ada Raymond Tersoo, Iorshagher Sixtus Terngu, Akogwu Emmanuel Akogwu. Survey and Identification of Macroinvertebrates Found in Some Ponds in Makurdi, Benue State Nigeria. International Journal of Ecotoxicology and Ecobiology. Vol. 2, No. 1, 2017, pp. $26-32$. doi: $10.11648 /$ j.ijee.20170201.14

Received: October 31, 2016; Accepted: December 7, 2016; Published: January 20, 2017

\begin{abstract}
Macroinvertebrates are important part of the aquatic food chain, vectors of some diseases as well as indicators of pollution in an aquatic environment. A survey of macroinvertebrates fauna of five ponds was done to identify the species present in these water bodies. The scoop net method was used and supplemented by hand picking method to collect macroinvertebrate samples. Results obtained showed that four classes of macroinvertebrates were present at the sampled sites and class insecta had the highest percentage occurrence (57.27\%) followed by gastropoda (31.10\%), malacostraca (6.69\%) and oligochaete $(4.94 \%)$ with the least occurrence. Analysis of variance showed that there was a significant difference $(\mathrm{p}<0.05)$ between the classes of macroinvertebrates sampled at all locations. Further analysis using Post hoc test (LSD) showed that the class malacostraca and oligochaete did not differ significantly $(\mathrm{p}>0.05)$ in distribution across all locations. Physio - chemical parameters showed no striking disparity in the water bodies sampled. The predominant aquatic flora encountered were Ipomoea aquatica, Nymphaea lotus and Graminae species. All macroinvertebrates belonged to three phylum: Annelida, Mollusca and Arthropoda.
\end{abstract}

Keywords: Macroinvertebrates, Survey, Ponds

\section{Introduction}

Macroinvertebrates are those animals that have no backbone and can be seen with the naked eye and can be retained by a $0.02 \mathrm{~mm}$ mesh net [1]. Macroinvertebrates can be quite large and include organisms such as crayfish, snails, clams, mussels, limpets, beetles, caddisflies, stoneflies, mayflies, hellgrammites, dragonflies, true flies, and some moths. However most are very small. The most diverse group and commonest of freshwater macroinvertebrates are the insects which account for $70 \%$ of known species.

The presence and distribution of aquatic macroinvertebrates in fresh water habitats, both streams, ponds and lakes is dependent on geographic location, elevation, stream gradient, flow rate and substrate type [2].

Macroinvertebrates are an important part of the aquatic food chain. A good number of them are primary consumers feeding mainly on plant material such as leaves and woody material. Others are collectors or filter feeders sieving materials in suspension or on mud surfaces. The secondary consumers, the first level carnivores feed on these macroinvertebrates and thus sustaining those higher in the trophic level such as fish, they thus play a crucial role in transfer of energy from primary producers and detritus to fish [3-5].

These ponds are a freshwater system and provide ideal habitat for most macroinvertebrates. Some macroinvertebrates have no history of serving as intermediate host of any disease, others have been associated with the transmission of many trematode diseases of man and livestock [6-10]. Among the major diseases of which macroinvertebrates such as gastropod snails serve as 
intermediate hosts are: schistosomiasis, fascioliasis and paragonimiasis. Schistosomiasis is of the greatest public health importance with about 200 million people infected in 76 endemic countries worldwide and about 600 million are at risk of infection [11].

Macroinvertebrates have been studied in Nigeria with specific bias to gastropod fauna $[6,7,12,11,13,14]$. This study was aimed at surveying and identifying macroinvertebrates found in some ponds in Makurdi, Benue State, Nigeria, in order to provide information on distribution and abundance of these macroinvertebrates species within these habitats.

\section{Materials and Method}

\subsection{The Study Area and Site Description}

The study sites were five water bodies in Makurdi the capital of Benue state, North-central Nigeria. A town that lies between Latitude $7^{\circ} 44^{\prime} \mathrm{N}$ and Longitude $8^{\circ} 32^{\prime} \mathrm{E}$ covering an area of $820 \mathrm{~km}^{2}$ with an estimated population of 348,990 people, "National Population commission of Nigeria" (2011). The main drainage system is River Benue with other smaller tributaries traversing the town. The vegetation type in Makurdi is guinea savannah with annual rainfall between 150 $-180 \mathrm{~m}$ and temperature of $26^{\circ} \mathrm{C}-29^{\circ} \mathrm{C}$.

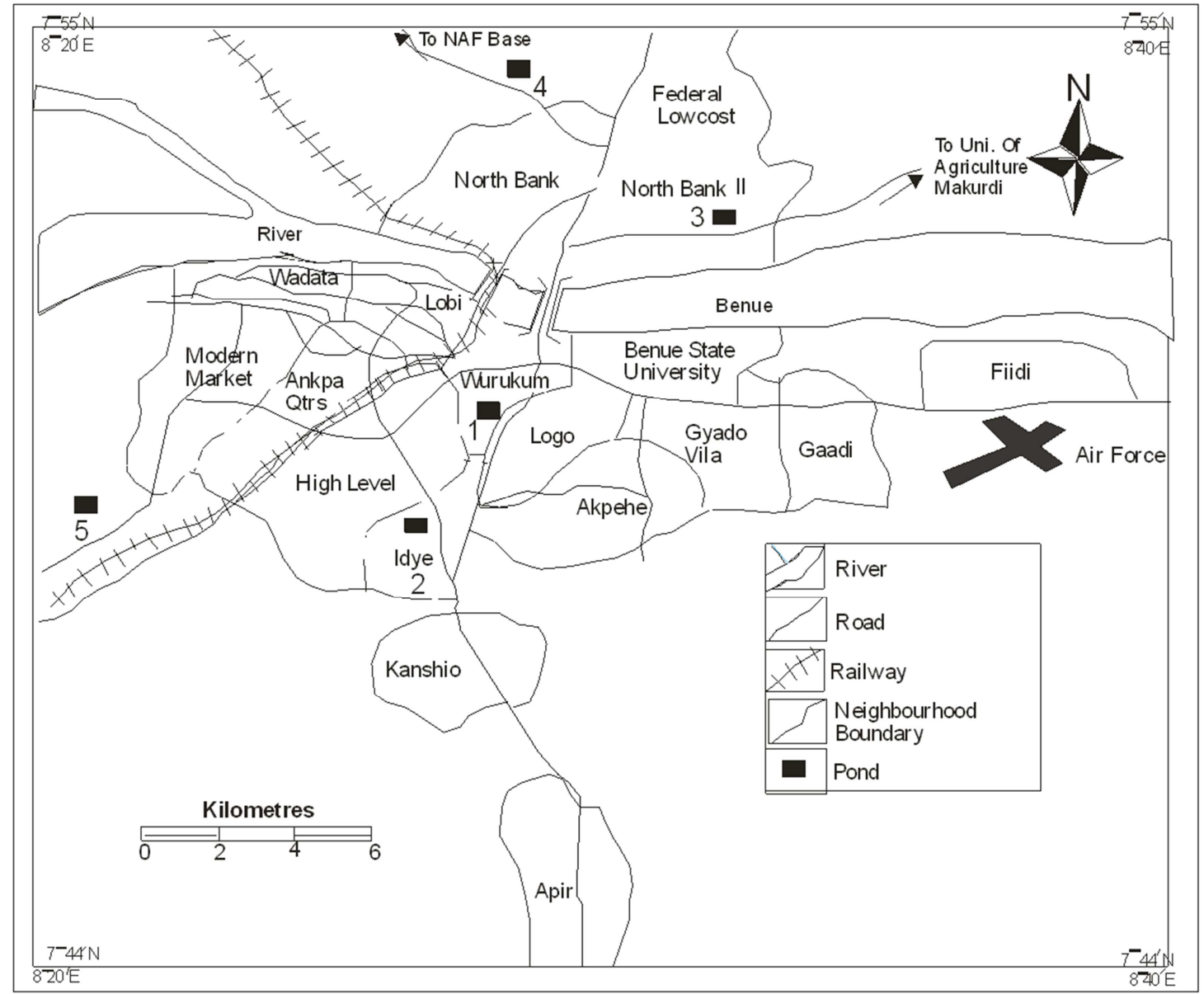

Figure 1. Map of Makurdi Town Showing Sampled Ponds.

Source: Ministry of Lands and Survey Makurdi

Legend:

Pond 1: Beside university of agriculture remedial school (U. A. R. S), Katsina-Ala street high level, Pond 2: Ishaya Bakut road before B-division police station, Pond 3: University of agriculture road, near college of advanced and professional studies (CAPS), Pond 4: Near mammy market off Lafia road north bank, Pond 5: Industrial layout off Naka road.

\subsection{Macroinvertebrate Collection}

The scooping net technique and hand picking of macroinvertebrates were employed. Samples were collected with a long-handled sieve net $(0.6 \mathrm{~mm}$ mesh size $)$. The net was dragged along the bottom of the pond for some distance after which it was shaken to drain off excess water. Large debris of leaves and grasses were screened out and then the contents turned into a wide mouthed plastic bottle. The samples were then taken to the laboratory for subsequent examination, identification and classification.

\subsection{Sample Sorting and Identification Method}

In the laboratory, the samples were passed through three sets of sieves $1^{\text {st }} 1 \mathrm{~mm}$, then $2 \mathrm{~mm}$ and finally $0.5 \mathrm{~mm}$ were used [15]. Sorting was made effective by adding moderate volume of water into container to improve visibility [15]. 
Large macroinvertebrates were picked with forceps. A dissecting microscope was used to assist in viewing and sorting of the more minute organisms which were picked with the aid of Pipette. All sorted organisms were placed in plastic bottles containing formalin and labeled according to ponds and dates of collection. The preserved animals were identified under light and stereo and dissecting microscope and counted. Identification was carried out using keys by [16 - 20].

\subsection{Data Analysis}

Data was entered into excel, managed and analyzed using SPSS. Statistical analysis of variance (ANOVA) was done to ascertain the level of significance in the distribution of macroinvertebrates from all locations sampled.

\section{Results}

\subsection{Class of Macroinvertebrates Sampled}

Macroinvertebrates sampled from all locations as shown in Table 1 were 344, comprising of four classes (Malacostraca, Gastropoda, Insecta and Oligochaeta). Class insecta (197) had the highest total number of species, followed by class gastropoda (107), malacostraca (23) and oligochaete (17) with the least number of species.

\subsection{Total Species Percentage Occurrence}

Total species percentage occurrence is presented in Figure 2 , with class insecta $(57.27 \%)$ having the highest percentage occurrence and class oligochaete $(4.94 \%)$ having the least. The dominance of the insects could be as a result of the location of the habitats and the presence of mud sediments while the low occurrence of the Oligochaetes could be as a result of natural factors.

\subsection{Statistical Analysis}

Statistical analysis of variance showed that there was a significant difference $(p<0.05)$ in the distribution of macroinvertebrates sampled at all locations. Post hoc using least significant difference (LSD) showed that class malacostraca and oligochaete did not differ significantly in distribution $(\mathrm{p}>0.05)$.

\subsection{Physio Chemical Parameters, Surrounding Vegetation and Occurrence of Macroinvertebrates at Each Pond}

Physio chemical parameters and occurrence of macroinvertebrates at each site is presented in Table 2; Lanestis libycus, Bulinus globosus, Nepa cinerea and Anaxipha exigua were present at all locations. Specific species of Macroinvertebrates with their number of occurrence and distribution at each location (Table 3) revealed that Anaaxipha exigua had the highest occurrence (123) while Paguristes frontalis occurs the least (1). C. A. P. $\mathrm{S}$ had the highest number of species (107) sampled while Mammy had the least number of species (26) sampled. The description of each habitat, surrounding vegetation and water contact activities are presented in Table 4; Graminae was the most dominant vegetation found at most of the sample sites.

\subsection{Monthly Distribution of Macroinvertebrates}

In figure 3; it was observed that there was a decline in the distribution of both class malacostraca and gastropoda as the dry season approached hence in the month of December both recorded values of zero at all the sampled habitats. Class insecta and oligochaete kept increasing as we approached the dry season with the peak been during the month of November hence it could be as a result of both classes require a little amount of moisture to exist.

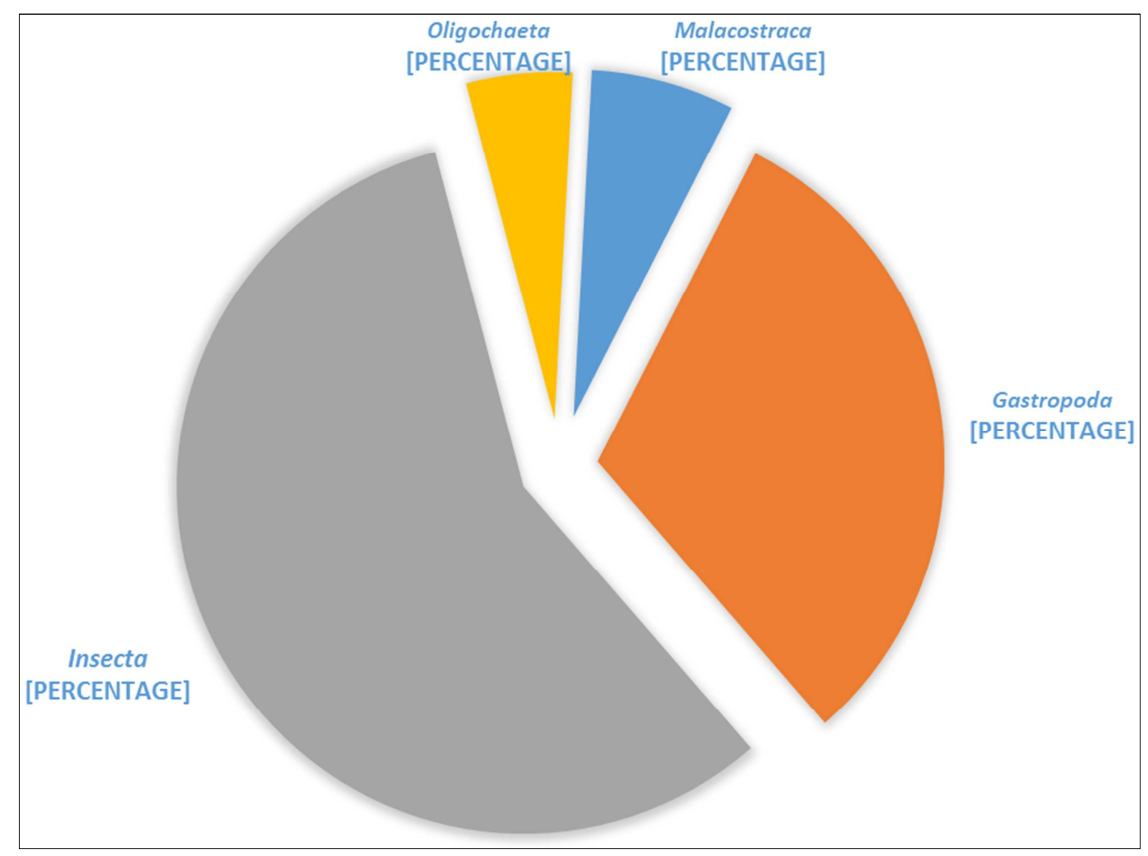

Figure 2. Percentage occurrence of macroinvertebrate. 


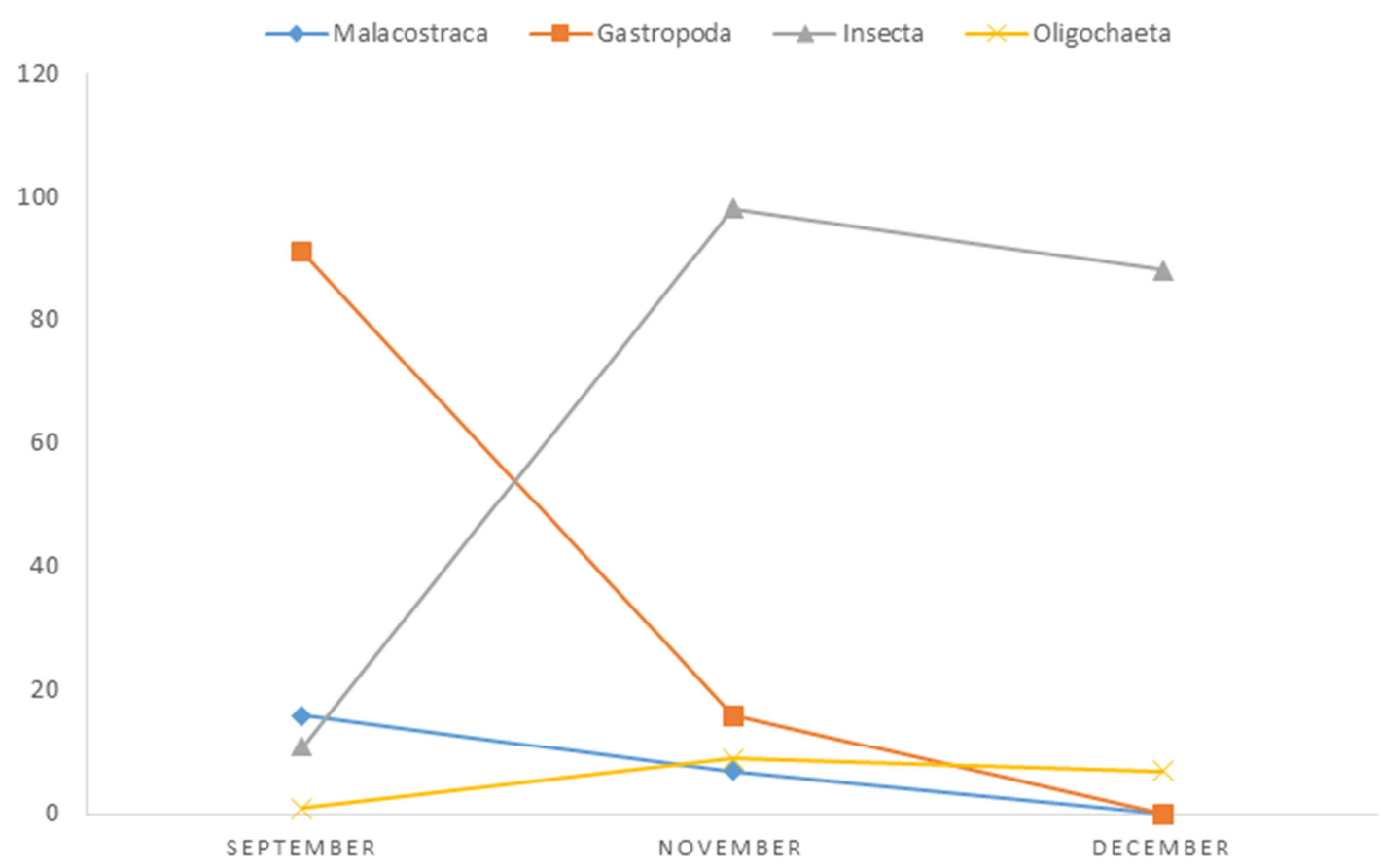

Figure 3. Monthly distribution of the Microinvertebrates.

Table 1. Occurrence of Macroinvertebrates sampled at all locations.

\begin{tabular}{llllllll}
\hline CLASS & $\begin{array}{l}\text { University of Agriculture } \\
\text { Remedial School }\end{array}$ & B-Division & $\begin{array}{l}\text { LOCATIONS } \\
\text { Industrial Layout }\end{array}$ & CAPS & Mammy & SPECIES TOTAL & MEAN \\
\hline Malacostraca & 4 & 0 & 1 & 16 & 2 & 23 & 4.6 \\
Gastropoda & 30 & 23 & 24 & 15 & 15 & 107 & 21.4 \\
Insecta & 51 & 25 & 46 & 66 & 9 & 197 & 39.4 \\
Oligochaeta & 1 & 3 & 3 & 10 & 0 & 17 & 3.4 \\
& & & & & & 344 & \\
\hline
\end{tabular}

Table 2. Physio-chemical parameters and Macroinvertebrates occurrence at habitats.

\begin{tabular}{|c|c|c|c|c|c|c|c|c|c|c|c|c|c|}
\hline \multirow[t]{2}{*}{ LOCATIONS } & \multicolumn{4}{|c|}{ PHYSIO-CHEMICAL FACTORS } & \multicolumn{9}{|c|}{ TYPES OF SPECIES } \\
\hline & pH & $\mathbf{T}\left({ }^{\circ} \mathbf{C}\right)$ & $\mathrm{DO}_{2}(\mathrm{mg} / \mathrm{L})$ & WC (ppm) & C.c & P.f & $P . m$ & L.l & B.g & B.f & N.c & A.e & L.t \\
\hline U.A.R.S & 6.80 & 28 & 1.4 & 257 & + & - & + & + & + & + & + & + & + \\
\hline B-Division & 7.60 & 27 & 1.5 & 241 & - & - & - & + & + & - & + & + & + \\
\hline Industrial Layout & 7.63 & 28 & 1.8 & 97 & + & - & - & + & + & - & + & + & + \\
\hline C.A.P.S & 7.06 & 29 & 1.9 & 52 & - & + & + & + & + & - & + & + & + \\
\hline Mammy & 8.04 & 29 & 1.3 & 91 & - & - & - & + & + & - & + & + & - \\
\hline
\end{tabular}

Legend: $\mathrm{DO}_{2}$-Dissolved oxygen; W.C - Water Conductivity; T- Temperature; C.c - Cambarida camburus; P.f - Paguristes frontalis; P.m - Penaeus monodon; L.1 - Lanestis libycus; B.g - Bulinus globosus; B.f - Bulinus forskalii; N.c - Nepa cinerea; A.e - Anaxipha exigua; L.t - Lumbricus terrestris; U.A.R.S University of Agriculture Remedial School; C.A.P.S - College of Advance and Professional Studies; +Present; -Absent;

Table 3. Specific species of Macroinvertebrates sampled.

\begin{tabular}{|c|c|c|c|c|c|c|c|}
\hline \multirow{2}{*}{ CLASS } & \multirow{2}{*}{ SPECIES } & \multicolumn{5}{|c|}{ LOCATION OF PONDS } & \multirow{2}{*}{ TOTAL SPECIES } \\
\hline & & U.A.R.S & B-DVISION & INDUSTRIAL LAYOUT & C.A.P.S & МАMMY & \\
\hline \multirow{3}{*}{ Malacostraca } & Cambarida camburus & 1 & - & 1 & - & - & 2 \\
\hline & Paguristes frontalis & - & - & - & 1 & - & 1 \\
\hline & Penaeus monodon & 3 & - & - & 15 & 2 & 20 \\
\hline \multirow{3}{*}{ Gastropoda } & Lanestis libycus & 14 & 12 & 19 & 6 & 9 & 60 \\
\hline & Bulinus globosus & 10 & 11 & 5 & 9 & 6 & 41 \\
\hline & Bulinus forskalii & 6 & - & - & - & - & 6 \\
\hline \multirow{2}{*}{ Insecta } & Nepa cinerea & 15 & 16 & 18 & 23 & 2 & 74 \\
\hline & Anaxipha exigua & 36 & 9 & 28 & 43 & 7 & 123 \\
\hline Oligochaeta & Lumbricus terrestris & 1 & 3 & 3 & 10 & - & 17 \\
\hline TOTAL & & 86 & 51 & 74 & 107 & 26 & 344 \\
\hline
\end{tabular}


Table 4. Description of activities characteristic of each habitat and their surrounding vegetation.

\begin{tabular}{|c|c|c|c|}
\hline NAME OF SITE & DESCRIPTION & WATER CONTACT ACTIVITY & VEGETATION COMPOSITION \\
\hline U.A.R.S & Water bank is swampy along bank road & Washing of automobiles fishing & Imperia cylindrical Nymphae. \\
\hline B-Division & Swampy area near police B-Division & $\begin{array}{l}\text { Rice cultivation, fishing, snail } \\
\text { collection }\end{array}$ & Ipomea, graminae, Nymphae. \\
\hline Industrial Layout & Pond located at industrial layout off Naka road & Fishing, swimming snail collection. & Graminae, Nymphae \\
\hline Mammy & $\begin{array}{l}\text { Pond located just before Army barracks mammy } \\
\text { market. }\end{array}$ & Automobile washing, snail collection. & Ipomea, graminae. \\
\hline C.A.P.S & $\begin{array}{l}\text { Pond beside the main road just before College of } \\
\text { Advance and Professional Studies. }\end{array}$ & Domestic use, fishing, irrigation. & Impomea, graminae \\
\hline
\end{tabular}

\section{Discussion}

The macroinvertebrate fauna of the ponds in Makurdi is similar to that of other Nigerian and African fresh water bodies including River Benue and its tributaries, River Galma, Ibiekuma River, Ikpoba River, Asejire reservoir [11, $15,21,22,23,24,25]$ with respect to species composition. Most of the species (Bulinus globosus, Lanistes libycus, Lymnea natalensis and Nepa cinerea) recorded have been identified by other works and are known to occur in most parts of Nigeria [24, 26, 29, 30].

Class insecta had the highest occurrence (57.27\%) and this is similar to the findings of Asibor [24], Adeymi et al [27], and Olumukoro et al [28] who obtained more organisms of the class insecta than any other species and asserted that the source of species was rich in fauna composition, the ponds were undisrupted and not affected by inert pollutants and fairly clean and unpolluted. The results of this survey also revealed that the macroinvertebrate community of the five (5) ponds are rich in class Gastropoda and Insecta, while Malacostraca and Oligochaeta are poorly distributed within the ponds. High abundance of the class Insecta and Oligochaeta were recorded in the month of November, when the rain has ceased and dry season just commencing while that of Malacostraca and Gastropoda species kept decreasing as the dry season sets in and both reached zero during the month of December (as shown in figure 3). Reason for these scenarios been that Insecta and Oligochaeta species need just little or moderate amount of moisture to survive while Malacostraca and Gastropoda need a lot of water to exist.

Class Malacostraca and Oligochaeta show a low conservation value (moderate to poor community of common specie), while class Gastropoda and Insecta show a high conservation value (a rich community of common macroinvertebrate specie and a number of local specie). However, C. A. P. S has more specie richness and diversity, this could be attributed to the presence of high dissolve $\mathrm{O}_{2}$ with the pond been just subjected to domestic activities, irrigation and fishing. These attributes hence creates a littoral area which support the growth and abundance of macrophytes which serve as food source for the Macroinvertebrates [24]. Mammy the least in terms of specie richness and diversity among the five ponds surveyed. This could be attributed to the fact that the water contact activity involves the use of automobiles that are washed into the habitat hence affecting the amount of dissolved $\mathrm{O}_{2}$ present in the habitat due to release and reaction (with the available $\mathrm{O}_{2}$ ) of chemical substances like engine oil, grease and hydraulic and therefore reducing the population of Macroinvertebrates. In terms of species occurrence Anaxipha exigua occurred the most (123) and highest at C. A. P. S (43), this could be as a result that $A$. exigua is known to occur in low lands and were vegetation is dense, which is a characteristics of all the habitats surveyed but most especially that of C. A. P. S [31], while $P$. frontalis occurred least (1) and found just at C. A. P. $\mathrm{S}$, this could be as a result of the specie been a scavenger [32] and C. A. P. S habitat is more characterized by activities that could leave dead animals or food materials for scavenging and another reason for its low occurrence could be as a result of the period in which this research was carried out.

Physio - chemical parameters did not show any striking disparities with $\mathrm{pH}$ fluctuating from slightly acidic to slightly alkaline with range of values $(6.80-8.04)$ at the different ponds and agrees with Olumukoro [29], and Omudu [11], however it differs from the findings of Igbinosa et al [14] who observed variations in the Physio chemical parameters of freshwater Ecosystems of Ovia in Edo state, Nigeria. The most dominant vegetation (Graminae) observed agrees with the work of Omudu [11]. The Lumbricus terrestris, Bulinus globosus, Nepa cinerea and Anaxipha exigua showed no habitat restrictions as they occurred in the five ponds. Their presence might be as a result of the fact that there was no human activity recorded in the ponds during the study period. Oligochaeta can also be described as deposit feeders, as such more tolerant to silting and decomposition than other groups of macroinvetebrates which agrees with Olumukoro [29].

\section{Conclusion}

This study have revealed that ponds in Makurdi are a good habitat for Macroinvertebrates and there is a little variation in their distribution in the ponds surveyed. All the sampled locations have vegetation growing in or around them and factors which influenced the abundance and distribution of macroinvertebrates are the nature of the water body, habitat richness and stability, immediate substrate of occupation, tropic condition, ressource partitioning and predation. These factors, coupled with habitat differences observed in this study, acted singly or in combination, to influence the variation in identification/abundance and distribution of macroinvertebrate of the five ponds. 


\section{Appendix}

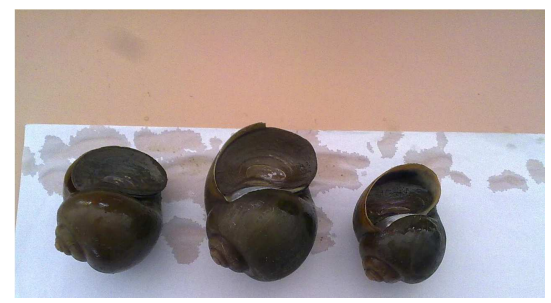

Figure 4. Lanistes Libycus (Snail).

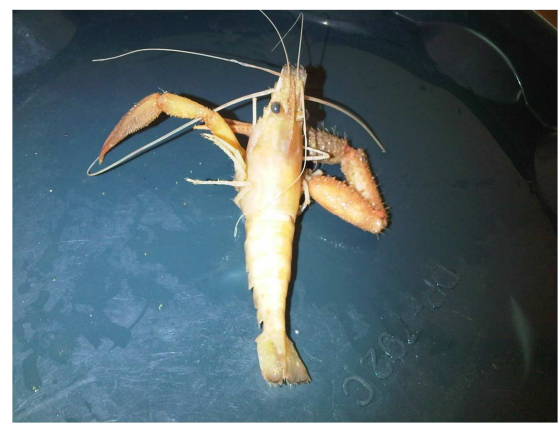

Figure 5. Cambarida camburus (Crayfish).

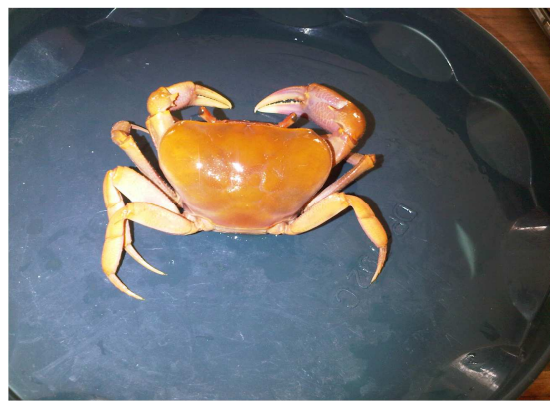

Figure 6. Paguristes frontalis (Crab).

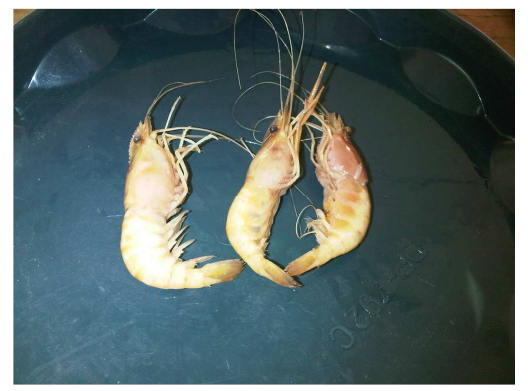

Figure 7. Penaeus monodon (Prawn).

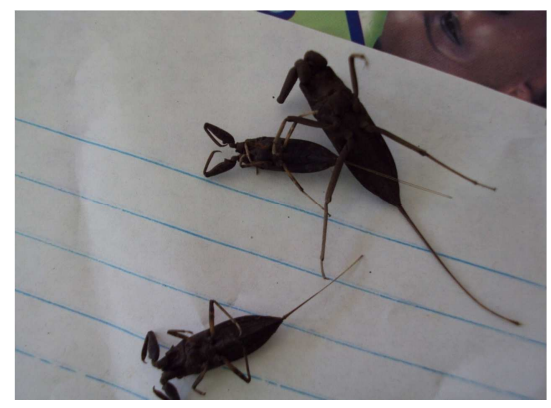

Figure 8. Nepa cinerea (Water scorpion).

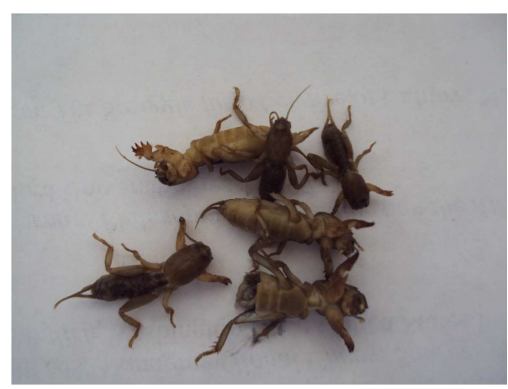

Figure 9. Anaxipha exigua (Mud cricket).

\section{References}

[1] J. Davis and F. Christidis. A Guide to Wetland Invertebrates of Southwestern Australia, Western Australian Museum, Perth.pgs 45-54. 1997.

[2] M. T. Barbour, J. Gerritson, B. D. Snyder and J. B. Stribling. Rapid bio assessment protocols for use in streams and wadeable rivers: Periphyton, benthic Macroinvertebrates and fish, $2^{\text {nd }}$ edition, pgs 86-94, EPA/841/B-99/002. Washington, DC: U. S. Environmental Protection Agency. 1999.

[3] P. Turcotte and P. P. Hamper. The Macroinvertebrate Fauna of a small stream. Freshwater Biology, 12: 411-419. 1982.

[4] D. T. McQueen, J. R. Post and E. I. Mills. Trophic relationships in freshwater pelagic ecosystems, Journal of Fisheries and Aquatic Sciences, 43: 1571-1581. 1986.

[5] J. M. Hanson. Macroinvertebrate Size Distribution of two contrasting Macrophyte Communities. Freshwater Biology, 24 481-491. 1990 .

[6] E. U. Imafidon. Ecological Studies of freshwater snails in Ibadan, Nigeria. Nigerian Journal of Parasitology, 12: 59-63. 1991.

[7] C. A. Emejulu, F. C. Okafor and J. C. Ezigbo. Gastropod fauna of Agulu Lake and adjoining freshwater systems in Anambra State, Nigeria. Journal of Aquatic Sciences, 7: 3538. 1992.

[8] F. C. Okafor. Distribution of freshwater gastropods in the lower River Niger and Cross River Basins of South-Eastern Nigeria with reference to their Trematode Infections. Biotropical Landwirtsch and Veterinary Medicine, 28: $207-$ 216. 1990.

[9] P. I. Agi and V. N. Okowuosa. Aspects of water quality of freshwater systems Harbouring snail vectors Schistosome parasites in Jos, Nigeria. Journal of Aquatic Sciences, 16 (1): 13-17. 2001.

[10] H. S. Idris and O. J. Ajanusi. Snail Intermediate Hosts and Etiology of Human Schistosomiasis in Katsina State, Nigeria. Nigerian Journal of Parasitology, 23: 145-152. 2002.

[11] E. A. Omudu and A. Iyough. Ecological Studies of Some Gastropod Fauna of Some Minor Tributaries of River Benue in Makurdi. Nigeria. Animal Research International 2 (2): 306-310. 2005.

[12] P. I. Agi. Survey of freshwater snail vectors of Schistosomiasis and study of Physio-chemical Parameters of the water bodies in Ogoni Communities, River State, Nigeria. Hydrobiological Journal, 21 (1): 31-36. 1995 
[13] O. J. Owojori, S. O. Asaolu and I. E. Ofoezie Ecology of freshwater snails in Opa Reservoir and Research farm Ponds at Obafemi Awolowo University, Ile Ife, Nigeria. Journal of AppliedSciences, 6 (15): 3004-3015. 2006.

[14] B. I. Igbinosa, J. I. Izegaegbe, F. C. Okafor and D. A. Uhunwangho. Ecological Survey of Freshwater Ecosystems of Ovia, Edo State Nigeria for Gastropod Molluscs. Animal Research International Journal. 12 (2): 2171-2177. 2015.

[15] T. J. A. Akaahan, P. A. Araoye, and F. M Olabanji. Macroinvertebrate fauna group and their relationship with environmental variables in River Benue at Makurdi, Benue State Nigeria. Journal of Ecology and the Natural Environment, 6 (8): 271-279.

[16] J. A. Day. A Monograph on the Polychaeta of Southern Africa Part 1 Errantia. British Museum of Natural History, London, pp: 458. 1967.

[17] R. W. Pennak. Freshwater Invertebrates of the United States. 2nd Edition. John Wiley and Sons, New York, pp: 810.1978.

[18] R. W. Merritt and K. W. Cummins. An Introduction to the Aquatic Insects of North America. 3rd Edition, Kendall-Hunt, Dubuque, IOWA, pp: 862. 1996.

[19] R. W. Bouchard. Guide to Aquatic Invertebrates of the Upper Midwest: Identification manual for students, citizen monitors and aquatic resources professionals. Water Resources Centre, USA. 174pp. 2004.

[20] P. S. Verma, and V. K. Aggarwal. A Manual of Practical Zoology: Invertebrates. S. Chand \& Company Ltd, New Delhi. 647 pp. 2010.

[21] J. A. Adakole. Benthic macroinvertebrates as indicators of environmental quality of an urban stream, Zaria, Northem Nigeria. Journal of Aquatic Sciences vol. 18 (2): 85-92. 2003.

[22] C. A. Edokpayi and E. C. Osimen. Hydrobiological studies on Ibiekuma River at Ekpoma, Southem Nigeria, after impoundment; the faunal characteristics. African Journal of Science and Technology (AJST) Science and Engineering Series 2 (1); 77-81. 2001.
[23] A. E. Ogbeibu and B. J Oribhabor. The Ecological impact of stream regulation using benthic macroinvertebrates as indices. Journal of Aquatic Sciences, 16 (2): 139-143. 2001.

[24] I. G. Asibor. Seasonal Biodiversity Assessment of Benthic Macroinvertebrate of Asejire Reservoir, Southwest Nigeria. Journal of Sustainable Development; 8 (2): 257-269. 2015.

[25] J. B. Edward and A. A. A. Ugwumba. Macroinvertebrate fauna of a Tropical Southern Reservoir, Ekiti State, Nigeria. Continental Journal of Biological Sciences 4 (1): 30-40. 2011.

[26] I. Okpalla. Studies on Schistosomahaemastoma infection in school children in Epe, Western Nigeria. West African Medical Journal, 10 (6): 402-412. 1961

[27] S. O. Adeyemi1, I. A. Adikwu, P. M. Akombu. and J. T. Iyela. Survey of Zooplanktons and Macroinvertebrates of Gbedikere Lake, Bassa, Kogi State, Nigeria. International Journal of Lakes and Rivers (IJLR) 2 (1): 37-44. 2009.

[28] J. O. Olomukoro, I. M. Osamuyiamen, A. Dirisu. Ecological Survey of Macrobenthic Invertebrates of Selected Ponds in Agbede Flood Plain, Southern Nigeria. Journal of Biology, Agriculture and Healthcare. Vol 3, No (10): 2224-3208. 2013.

[29] J. O. Olomukoro, and E. O. Oviojie. Diversity and Distribution of Benthic Macroinvertebrate Fauna of Obazuwa Lake in Benin City, Nigeria. Journal of Biology, Agriculture and Healthcare. Vol 5, No (1): 2224-3208. 2015.

[30] I. T. Nathaniel. The Macro-invertebrate benthic fauna and bottom sediment studies of Opa Reservoir in Obafemi Awolowo University, Ile-Ife, Nigeria. M. Phil. Thesis Obafemi Awolowo University, Ile-Ife. (2001)

[31] http://insects.ummz.lsa.umich.edu/fauna/Michigan_Cicadas/M ichigan/Index.html. Retrieved $13^{\text {th }}$ November, $201 \overline{6}$.

[32] "Paguristes frontalis (H. Milne-Edwards, 1836)". Australian Faunal Directory. Department of the Environment, Water, Heritage and the Arts. Retrieved $13^{\text {th }}$ November, 2016. 